\title{
The Investigation of Human Values Perceived from the Use of Social Media of Secondary School Students ${ }^{i}$
}

\author{
Ahmet Kara ${ }^{1, *}$, Hatice Tekin ${ }^{2}$ \\ ${ }^{1}$ Faculty of Education, Department of Educational Sciences, Inonu University, Malatya, Turkey \\ ${ }^{2}$ Ministry of National Education, Turkey
}

Copyright $\bigcirc 2017$ by authors, all rights reserved. Authors agree that this article remains permanently open access under the terms of the Creative Commons Attribution License 4.0 International License

\begin{abstract}
This research has been carried out to investigate the relation between social media usage of secondary school students and their perceived human values. The population of the research consisted of 1952 students, of which $48 \%$ were female and $52 \%$ were male, $7^{\text {th }}$ and $8^{\text {th }}$ grade students attending secondary schools in central Adıyaman in 2014-2015 academic years. Nine secondary schools were selected randomly. Data for the research were collected through "Human Values Scale" developed by Dilmaç [1], and "Social Media Usage Motivation and Satisfaction Scale" developed by Ök [2]. Data were analyzed with SPSS using independent samples t-test and one-way-ANOVA analyzes. The research showed that the longer social media usage led to the lower total points from "human values scale" in certain subscales and the higher points in others; and the gender was determined to be significant in favor of male students in social media usage and satisfaction. In the light of results some suggestions were made for researchers.
\end{abstract}

Keywords Social Media, Values, Values Education, Secondary School Students

\section{Introduction}

Communication that is the fundamental instrument for socialization from past to present is the process of transferring the intended meaning to the addressee through the symbols and signs agreed before mutually. The communication has nonverbal oral and written types. Practicing today's Technologies into communication has enhanced the communication process in a variety nonesuch to the previous, and the domain has become an attractive area of investment for the entrepreneurs. The previous existence reasons for the computers and tablets as the final target product have recently fallen behind being a communication tool. This environment the electronic instruments open for themselves in communication creates social media. Use of computers as one of the fundamental factors of the information age we live in and the internet that has developed at an unprecedented pace since $90 \mathrm{~s}$ have continued to become widespread all around the world. This popularization has transformed the societies. The educational system that has to reflect the changes in all sub-systems creating the society to its body rapidly has been in a struggle for using the computer-and internet-based technologies commonly and efficiently [3]. Efficient use of technological tools and instruments included in the educational systems has revealed new approaches in teaching methods and strategies.

Social media is generally used for communication, friendship, socialization, and sharing. However, use of social media technologies in education has recently become a current issue. Including the social media websites into the educational processes is remarkable. Teachers can create a community with simple steps, and can establish communication sharing with their students. All these provide conveniences for the users. On the other hand, new values and understandings appear in constantly changing world. As expressed by Güngör [4], technology change affects our values, as well. When the speed of technological improvement is faster than the speed of social development, then human values are possible to be mentioned as being in danger. In this changing process, we have to manage the change without disturbing the network between our tangible and intangible values. If we can fulfill this, the process of reaching to human values as the main target of life will be easier, and we will place our life standards on a stronger base in the society we live in.

Task and responsibility of education related to acquiring moral and human values have changed out of families, and the responsibility of schools has increased. Families' invoking the educational function they have to the schools together with their general educational expectations has also increased the responsibilities of schools. It is clear that ignoring the position schools undertake will not provide a benefit in terms of values education. According to Çağlar [5], improving technology has given acceleration to education 
during the process of knowledge creation and transfer. The relationship between the people weakened, and pushed into the background. This result has made the values education in educational institutions more important.

In reference to the fact that individuals acquire values in their adolescent period, it is observed in students in secondary education period that use of social media has gradually increased, and virtual friendship, telling lies more easily and dissatisfaction have all increased, as well, through the developing technology. Because easier irresponsible behaviors are possible to be observed and establishing friendships is easier because there is no face-to-face communication. Such behaviors can cause social problems in the years ahead. Therefore, basic human values perceived by the secondary education students through the use of social media were investigated in this research.

\subsection{Problem and Sub-Problems}

The main problem of the research was expressed as "Is there a significant difference between social media use and perceived human values of the secondary education schools in terms of some variables?" In reference to this aforementioned problem, four sub-problems were determined in the research: Is there a significant difference in attitudes of secondary education schools towards social media use motivations and perceived values in terms of their (1) gender, (2) frequency of using social networks, and (3) the time for daily internet use? In the fourth sub-problem of the research, "Is there a significant difference between social media use motivations and perceived human values of the secondary education students?" was tried to be determined.

\subsection{Importance of the Research}

When the general objectives of Turkish National Education, it can be noticed to be including the expression of "raising individuals who adopts, protects and develops national, moral, human, spiritual and cultural values of their nation, who have a personality and character balanced and healthy bodily, mentally, morally, spiritually and emotionally, and have a free and scientific power of thinking and broad worldview, who is respectful to human rights, who values personality and enterprises, who bear responsibility for their society, and who are constructive, creative and productive" [6]. With reference to these expressions, character education is noticed to be one of the fundamental objectives of our national education and including the required values. The schools should provide students to make accurate decisions, make correct preferences, and display moral behaviors adopted and accepted in their societies. These values are accepted as a piece of school life. The classroom is an environment where daily-basis positive values are strengthened, modeled and practiced, but unintended negative behaviors are also known to be acquired. In this sense, determining the values schools convey, provide to be experienced and transfer to the future generations are remarkable in this research. Determining these accurately is a reference for determining more efficient, more productive and more realistic teaching activities and objectives.

It is known that students postpone the tasks they should fulfill academically while spending time on web environments. The time spent on the internet affects the course success of the students, as well. In accordance with the findings revealed through investigating the social media use of the students, in the light of the findings of using social media situation among students, certain suggestions can be offered to the psychological counseling and guidance centers at school on approaches to the students experiencing problems. Furthermore, it is also aimed to help families on social network websites' affecting dimension of students' academic behaviors. The target aimed to be reached through the values education is raising honest individuals having targets, character, ethics and personality. Developing behavioral patterns in students such as acquiring the basis for the emotional trust, reasoning the events displaying intelligent attitudes towards conflicting situations, adaptation, and solving the problems with accurate examples should be targeted. It is not possible to reach these objectives without describing the issue. For that reason, describing the current status of values education benefiting from the descriptive method is remarkable in this research.

\subsection{Literature Review}

It is not possible to find definitions that are exactly the same with each other on social media. "The core element of the definitions of social media is the way that the internet and other new technologies are being used to move away from media that was essentially a one-to-many model, for example broadcast, towards a many-to-many model, such as Facebook" [7]. After 2005s, a change has been experienced in social network websites due to the improvements in Web 2.0 technologies, and their popularities have increased. Moreover, the time users spend on social networks with several members from different age groups has had a significant increase within the period from their beginning to now [8]. The dialogues and shares individuals have with each other on social networks create the social media, in general. Social media is one of the newest ideas providing opportunities as a new type of online media where the highest level of shares is offered.

According to Lerman [9] social media websites have four common properties:

1. The users can create contents on various media types, and make contributions to these contents.

2. The users can tag the contents.

3. The users can evaluate the content through either an active voting or passive using.

4. The users can create social media networks defining common areas of interest such as persons and friends with other users. 
Through the social media, individuals have the opportunity of expressing themselves at a degree they have never had. By means of social media, individuals, if they requested, can reach to large masses, and share their ideas, interpretations, experiences and information with them. Through the social media, individualization appears on the one hand, and a new type of socialization is created, on the other. The users reestablish and develop the social relationships in virtual environments upon social networks they consider as trustful and are familiar from the real life [10].

Paul \& Lee [11] and Engelberg \& Sjöberg [12] found internet addiction to be higher among men and children from low income families, adolescents were inclined to use technology although they were not open to access the information from various sources, they frequently used the social media and online games for leisure. They also added internet literacy in publishing and technology increased the likelihood of internet addiction. Although using social media instruments well creates the expectation of academic success, technical literacy skill is not a good predictor for the academic success. The adolescents who can reach to information from different sources and have ideas on the source of information are academically more successful.

Shaw and Gant [13] found a positive correlation between internet use and depression, loneliness and stress. Social media use has been noticed to have a recovering effect upon loneliness, self-confidence and depression. Over-participating into online activities has the potential of social isolation. Mazalin and Moore [14] expressed that not completing the social anxiety and personality development was correlated with heavy internet use; and Valkenburg, Peter and Schouten [15] mentioned that the frequency for using the social network websites had an indirect effect upon self-respect and psychological mood of the students, and the number of friends in social networking websites and the feedbacks for the shares on profile affected self-respect of the adolescents.

All previous studies have revealed that the internet has both positive and negative effects upon human psychology. Whereas social media use has a negative effect upon loneliness, it has a positive effect upon the social support. Such studies have been carried out more for adults, and the number of studies carried out on children is limited. Ando, Takahira and Sakamoto [16] reported that social networking websites have rapidly become popular among children and adolescents, and provided opportunities for creating a broad surrounding, and controlling the privacy and sincerity. On the other hand, social networking websites have caused dangers such as cyber-bullying, loss of privacy and establishing undesirable relationships. Livingstone and Brake [17] discussed the necessity for technology and media literacy trainings considering the opportunities and risks of social media.

One of the social networks that provides an environment where individuals can spend time together on a virtual platform is Facebook.com. Apart from this, it has been found in some researches carried out with university students in our country that Facebook was the one that was mostly used among the social networks [18] [19] [20] and the frequency of using was high [21]. There are several reasons for Facebook to be preferred at a high level. These reasons are its providing a multimedia with a rich variety, easy sharing establishing link with other websites, the possibility for connecting with broad communities providing preferences such as group, activity and application, providing the opportunity of online and offline chat, having an infra-structure providing support for running various games on mobile phones, having visually and Turkish language support [22].

It was expressed in the researches carried out on benefiting from Facebook in education that Facebook accommodated itself to the university environments of students, develop the communication of students with the other students [23] students' revealing their own ideas, supporting the students on using their researching, questioning and problem-solving skills, providing the active participation of students, their asking questions to the people around them, use of this network's not requiring much pre-knowledge, its being open to peer education, its supporting learning through educative games and multimedia, and revising the process due to not deleting the shares [24].

Moreover, Tiryakioğlu and Erzurum [25] determined that Facebook was also used and adopted by the lecturers, and could provide significant benefits to both lecturers and students with increasing learning communities and increasing lecturer-student and student-student interaction as being supportive of traditional teaching and including more learning styles.

\subsection{Values}

Whereas Güngör [4] expressed the concept of value as "the belief on either something is desirable or undesirable;" Çağlar [5] expressed values as the cultural element that appeared as a standard in thoughts, attitudes and actions of individuals. Erdem [26] defined values as the tendency of preferring a situation to another. Başaran [27] defined the value as a quality and quantity determining the importance an object, process, idea and/or action carry in an organization, and used as an instrument for evaluating an object, process, idea and/or action. The private schools and institutions have recently spent energy and sources for the programs and attempts designed for encouraging values and behaviors of their students. Values education has created a part of curriculum in different educative conditions all around the world. The countries such as India, Australia and Singapore regard practicing values education through a well-defined curriculum and course program. The observations in Australia have the "potential of supporting the social developments of the students strengthening the relationships between students, and students and teachers and 
transforming the learning environment and surrounding and harmony and inclusion of schools." In Turkey, because the young and children grows at an instant-pleasure, easiness, distrust and fear-based survival and existence age, the need felt towards values education has been discussed to be increasing. The socio-cultural changes such as transition from extended family to nuclear family, extreme competition, familial expectations, commercialization of education, negative effect of media, misuse of information technology, globalization, and consumerism are noticed to create a remarkable pressure leading to the devastation of values upon children, families and schools. The schools consider values education as a solution for coping with the difficulties of the present day finding new ways to educate students. Starting from here, the young and children should be only trained on academic information they are required to know, and they should also be trained on "Being a Human" and living together. While training the students on values, they are provided to think, reason, question investigate, be interested and behave appropriately. The values are developed through allowing the students to speak, discuss and looking for their own values, not through obliging them to memorize the words.

No education is independent from the values, and objectives of education include the objectives of values education. Therefore, values education should not be considered as a load or supplementary to a curriculum, and activity. In fact, it should not be perceived as a different task for the schools engaged in developing academic success and learning of students. Undoubtedly, values education is under the responsibility of both parents and public; however, the schools as organized institutions should take the main responsibility of developing values in students. These efforts should be regarded as investments made to construct the basis for lifelong learning, and to support social adherence, national unity and global integrity beside perfectness. The target to be fulfilled with values education is to raise moral, hardworking, honest individuals with a good personality. Therefore, affective dimension is always prominent during the educational process. Ignoring the affective dimension in education will cause a significant potential of people not to be used. The affective dimension including the elements such as feelings, preferences, pleasures, beliefs, expectations, attitudes, feeling of appreciation, ethics and moral is an irreplaceable dimension for both individual and social life [28].

Recent technological improvements have caused some changes in our worldview, and it is certain that our beliefs and views have significant effects upon technological improvements. When the speed of technological improvements is faster than social development, human values are possible to be mentioned as being in danger. Furthermore, what is important during the process of development is providing the relationship between our spiritual values and material values to be mutual. If we can fulfill this, the process of reaching to human values as the main objective of life will be easier, and we will build our life standards in the society to a more solid ground [4]. In order for providing students to benefit from any environments in moral and values education, it is necessary to offer them some opportunities. Through the methods applied at home and at school, behavior model thought and rich learning environments provided students will be led to dispose the expected behaviors. Effects of moral and values education are more in environments enhanced with the contributions of modern equipment.

\section{Materials and Methods}

\subsection{Research Model}

In this study, screening model was used for analyzing the human values perceived with social media use of the secondary education students. A researcher who carries out a study with screening model investigates the subject directly, and make interpretations integrating his/her observations with the information $\mathrm{s} / \mathrm{he}$ finds and applying to relevant reference persons and the records kept before. In screening model, recording the events as they are and classification are the leading properties. However, interpretation and evaluation are obligations. Screening model serves for two purposes: recognizing the current conditions and solving the problem. In screening model, data is collected from a large area at a specific period; collected data should belong to common and several numbers of individuals, events and situations as convenient to statistical processes. There is no effort for affecting and changing the researched issue [29].

\subsection{Population and Sample}

The population of the research included secondary education students studying in Adiyaman provincial center (Turkey). For the sample, 9 different secondary education schools in Adiyaman provincial center were screened. For determining the research sample, stratified sampling method as one of the probability sampling methods was based, and 1952 students were included into the study. The probability sampling is selecting the units from the population with an equal possibility at every turn. Stratified sampling is used in situations when there are sub-stratum or sub-unit groups in a population determined with its borders [30].

In the study, $51.3 \%$ out of 1952 students creating the sample were male, and $48.7 \%$ were female. Numbers of female and male students were close to each other. In the research, $48.5 \%$ of the students studied at the $7^{\text {th }}$ grade, and $51.5 \%$ studied at the $8^{\text {th }}$ grade. Whereas $41.9 \%$ of the students did not use any social networks, $20 \%$ used social networks $1-2$ days a week and $10.6 \%$ used every day. Nearly $48 \%$ of the students use the internet and social networks for less than 1 hour or 1-2 hours when they connect to the internet. Ten percent of the students spend 2 hours and more 
on the internet.

Table 1. Distribution of the Sample According to the Independent Variables

\begin{tabular}{|c|c|c|c|}
\hline \multirow{4}{*}{ Gender } & & $\mathrm{N}$ & $\mathrm{F}(\%)$ \\
\hline \multirow{4}{*}{ Grade } & Female & 951 & 48.70 \\
\cline { 2 - 4 } & Male & 1001 & 51.30 \\
\cline { 2 - 4 } & $7^{\text {th }}$ grade & 946 & 48.50 \\
\hline \multirow{4}{*}{$\begin{array}{c}\text { Frequency of using } \\
\text { social networks }\end{array}$} & $1-2$ days a month & 1006 & 51.50 \\
\cline { 2 - 4 } & 1-2 days a week & 205 & 10.50 \\
\cline { 2 - 4 } & 3-4 days a week & 224 & 20.60 \\
\cline { 2 - 4 } & 5-6 days a week & 96 & 41.50 \\
\cline { 2 - 4 } & Every day & 207 & 10.60 \\
\cline { 2 - 4 } & Nonusers & 817 & 41.90 \\
\hline \multirow{4}{*}{$\begin{array}{c}\text { Daily internet usage } \\
\text { time }\end{array}$} & Less than 1 hour & 484 & 24.80 \\
\cline { 2 - 4 } & $1-2$ hours & 463 & 23.70 \\
\cline { 2 - 4 } & 2-5 hours & 145 & 7.40 \\
\cline { 2 - 4 } & More than 5 hours & 43 & 2.20 \\
\cline { 2 - 4 } & Nonusers & 817 & 41.90 \\
\hline & Total & 1952 & \\
\hline
\end{tabular}

\subsection{Data Collection Tools}

Two scales were used in this research. The first one was "Human Values Scale" developed by Dilmaç [1] for the students at secondary education grade in order to determine the values perceived by the students. The items in the scale were on five-point Likert type. The sub-dimensions of the scale were specified as responsibility, friendship, respect, honesty, and tolerance. The increase/decrease in scores indicated individuals to have/did not have more human values. In this study, Cronbach Alpha internal consistency coefficient was calculated to be .924 when the scale was performed to 1952 students. The reliability coefficient KMO was found to be .946 . Considering these results, the scale was found to be valid and reliable. The second scale was developed by Ök [2] for determining the social media use motivations and satisfactions of the students. The items included into the scale as answers to the questions of "I use social media because..." were 1) Entertaining and Spending Time and Spending Time (İt needs my need for Entertaining and Spending Time, etc.); 2) Maintaining a relationship (I can establish contact with my friends, etc.); 3) Spending time (It makes me spend time when I get bored, etc.); 4) Virtual community (I can find more interesting people rather than the ones in real life, etc.); 5) Narcissism (I want to be easily recognized/known among the people, etc.); 6) Media habit
(Looking at the photograph albums has become a part of my life, etc.); 7) Being informed (It makes me have ideas on several issues, etc.); and 8) Personal status (For developing mu status/position in the world, etc.).

\subsection{Data Analysis}

The data obtained through performing the relevant data to the students in the sample group were evaluated in Statistics Packages for Social Sciences 20.0 program, and the data were evaluated according to independent samples t-test and one-way Anova analysis tests. Furthermore, Bonferroni and Kruskal-Wallis tests were performed for determining among which groups there were significant differences.

\section{Findings and Interpretation}

\subsection{Findings and Interpretation Related to the First Sub-Problem}

Results of the independent groups t-test performed for answering the question of "is there a significant difference between social media use motivations and perceived values of the secondary education students in terms of gender?" as the first sub-problem of the research were presented in Table 2.

When the data in Table 2 were analyzed, differences were noticed in terms of gender in averages of the answers of the secondary education students related to the social media use and values scale. According to the independent groups t-test results performed for determining whether these aforementioned differences were significant or not, significant differences were observed in nine out of ten sub-dimensions of the scale; female students had higher scores rather than the male students in values of responsibility $(\bar{X}$ male $=26.49, \bar{X}$ female $=27.55, \mathrm{t}=-5.306$, $\mathrm{p}<.05)$, friendship $(\bar{X}$ male $=27.88, \bar{X}$ female $=28.82, \mathrm{t}=-4.508$, $\mathrm{p}<.05)$, respect $(\bar{X}$ male $=27.69, \bar{X}$ female $=28.6, \mathrm{t}=-4.478$, $\mathrm{p}<.05)$, honesty $(\bar{X}$ male $=21.43, \bar{X}$ female $=22.66, \mathrm{t}=-8.166$, $\mathrm{p}<.05)$, tolerance $(\bar{X}$ male $=22.45, \bar{X}$ female $=23.62, \mathrm{t}=-6.371$, $\mathrm{p}<.05)$, and maintaining a relationship $(\bar{X}$ male $=16.45$, $\bar{X}$ female $=17.00, t=-2.682, p<.05$ ).

According to this, it was understood that female students had more responsibility, respect, honesty, and tolerance values and regarded maintaining the relationships more rather than the male students. In terms of virtual community $(\bar{X}$ male $=10.94, \bar{X}$ female $=10.15, \mathrm{t}=3.870, \mathrm{p}<.05)$, narcissism ( $\bar{X}$ male $=40.24, \bar{X}$ female $=36.88, \mathrm{t}=4.806, \mathrm{p}<.05)$, being informed and personal status $(\bar{X}$ male $=14.18, \bar{X}$ female $=13.57$, $\mathrm{t}=2.698, \mathrm{p}<.05$ ) dimensions, male students were determined to value more rather than the female students. 
Table 2. Independent Groups t-test Results of the Attitudes towards Social Media in Terms of Gender

\begin{tabular}{|c|c|c|c|c|c|c|}
\hline & Gender & $\mathrm{N}$ & $\bar{X}$ & SS & $\mathrm{t}$ & $\mathrm{p}$ \\
\hline \multirow{2}{*}{ Responsibility } & Male & 1001 & 26.49 & 4.58 & \multirow{2}{*}{-5.306} & \multirow{2}{*}{.00} \\
\hline & Female & 951 & 27.55 & 4.22 & & \\
\hline \multirow{2}{*}{ Friendship } & Male & 1001 & 27.88 & 4.71 & \multirow{2}{*}{-4.508} & \multirow{2}{*}{.00} \\
\hline & Female & 951 & 28.82 & 4.5 & & \\
\hline \multirow{2}{*}{ Respect } & Male & 1001 & 27.69 & 4.73 & \multirow{2}{*}{-4.478} & \multirow{2}{*}{.00} \\
\hline & Female & 951 & 28.6 & 4.13 & & \\
\hline \multirow{2}{*}{ Honesty } & Male & 1001 & 21.43 & 3.42 & \multirow{2}{*}{-8.166} & \multirow{2}{*}{.00} \\
\hline & Female & 951 & 22.66 & 3.19 & & \\
\hline \multirow{2}{*}{ Tolerance } & Male & 1001 & 22.45 & 4.05 & \multirow{2}{*}{-6.371} & \multirow{2}{*}{.00} \\
\hline & Female & 951 & 23.62 & 4.05 & & \\
\hline \multirow{2}{*}{ Entertaining and Spending Time } & Male & 668 & 35.29 & 7.69 & \multirow{2}{*}{-.876} & \multirow{2}{*}{.38} \\
\hline & Female & 467 & 35.69 & 7.41 & & \\
\hline \multirow{2}{*}{ Maintaining a relationship } & Male & 668 & 16.45 & 3.53 & \multirow{2}{*}{-2.682} & \multirow{2}{*}{.00} \\
\hline & Female & 467 & 17.00 & 3.2 & & \\
\hline \multirow{2}{*}{ Virtual community } & Male & 668 & 10.94 & 3.26 & \multirow{2}{*}{3.870} & \multirow{2}{*}{.00} \\
\hline & Female & 467 & 10.15 & 3.49 & & \\
\hline \multirow{2}{*}{ Narcissism } & Male & 668 & 40.24 & 11.5 & \multirow{2}{*}{4.806} & \multirow{2}{*}{.00} \\
\hline & Female & 467 & 36.88 & 11.7 & & \\
\hline \multirow{2}{*}{ Being informed and personal status } & Male & 668 & 14.18 & 3.83 & \multirow{2}{*}{2.698} & \multirow{2}{*}{.00} \\
\hline & Female & 467 & 13.57 & 3.7 & & \\
\hline
\end{tabular}

$\mathrm{Sd}=1950$

When the studies carried out on these were reviewed, it was noticed that Tekin Akdemir [31] expressed there was no significant difference in terms of gender in attitudes towards Facebook, and Argin [32] expressed no significant difference in attitudes towards social media. However, in the study carried out by Eser [33] investigating the relationship between human value levels and environmental attitudes of the elementary education students, human value scores of the female students were noticed to be higher rather than the male students. Gülnar, Balcı and Çakır [34] stated that male experiments regarded narcissism and self-presentation factors more.

\subsection{Findings and Interpretation Related to the Second Sub-Problem}

Results of the one-way variance analysis test performed for answering the question of "Is there a significant difference between social media use motivations and perceived values of the secondary education students in terms of the frequency of using social networks?" as the second sub-problem of the research were presented in Table 3. As could be seen in Anova test Table, the differences were significant in score averages of the students in responsibility (Fresponsibility $=3.716, \quad \mathrm{p}<.05$ ) dimension, friendship (Ffriendship=5.689, $\mathrm{p}<.05$ ) dimension, Entertaining and Spending Time and spending time (Fentertaining and Spending Time $=52.689, \mathrm{p}<.05$ ) dimension, in maintaining a relationship (Fmaintaining relationship $=34.973, \quad p<.05$ ) dimension, in virtual community (Fvirtual community12.397, $\mathrm{p}<.05$ ) dimension, narcissism (Fnarcissism=13.218, $\mathrm{p}<.05$ ) dimension, and in being informed and personal status (Fbeing informed and personal status=8.434, $\mathrm{p}<.05$ ) dimension.

As a result of the Levene test, Bonferroni test was conducted with responsibility, friendship, narcissism, getting informed and personal status dimensions in order to find among which groups the significance emerged. According to the result of Bonferroni test, the conscious of responsibility was more in students who did not use social media rather than the ones who used 1-2 days a month $(\bar{X} 1-2$ days a month=26.14, $\bar{X}$ no use=27.36). In terms of friendship dimension, the rate was higher in students who used social media every day rather than the ones who used 1-2 days a month, $1-2$ days a week and who did not use $(\bar{X}$ everyday $=$ $29.78, \bar{X}$ no use $=28.03, \bar{X} 1-2$ days a month $=27.76, \bar{X} 1-2$ days a week $=28.40$ ). According to the result of Bonferroni test, it was noticed that narcissist personality traits increased as the social media use increased in terms of narcissism dimension ( $\bar{X}$ everyday $=42.24, \bar{X} 5-6$ days a week $=40.64, \bar{X} 1-2$ days a month $=34.35, \bar{X} 1-2$ days a week $=38.64)$. Narcissist traits were the highest in students who used social media every day. Moreover, in terms of the being informed and personal status dimension, as the social media use of the student increased, the scores of being informed and personal status increased, as well.

Results of the Kruskal-Wallis test performed for Entertaining and Spending Time and spending time, maintaining a relationship and virtual community sub-dimensions according to the result of Levene's test were presented in Table 4. 
Table 3. ANOVA Test Results in terms of the Frequency of Using the Social Networks

\begin{tabular}{|c|c|c|c|c|c|c|}
\hline & & Sum of Squares & Df & Mean Square & $\mathrm{F}$ & $\mathrm{p}$ \\
\hline \multirow{3}{*}{ Responsibility } & Between Groups & 363.548 & 5 & 72.710 & \multirow{3}{*}{3.716} & \multirow{3}{*}{.002} \\
\hline & Within Groups & 38079.426 & 1946 & 19.568 & & \\
\hline & Total & 38442.975 & 1951 & & & \\
\hline \multirow{3}{*}{ Friendship } & Between Groups & 603.525 & 5 & 120.705 & \multirow{3}{*}{5.689} & \multirow{3}{*}{.000} \\
\hline & Within Groups & 41285.560 & 1946 & 21.216 & & \\
\hline & Total & 41889.086 & 1951 & & & \\
\hline \multirow{3}{*}{ Respect } & Between Groups & 129.030 & 5 & 25.806 & \multirow{3}{*}{1.293} & \multirow{3}{*}{.264} \\
\hline & Within Groups & 38849.072 & 1946 & 19.964 & & \\
\hline & Total & 38978.102 & 1951 & & & \\
\hline \multirow{3}{*}{ Honesty } & Between Groups & 92.569 & 5 & 18.514 & \multirow{3}{*}{1.636} & \multirow{3}{*}{.147} \\
\hline & Within Groups & 22026.766 & 1946 & 11.319 & & \\
\hline & Total & 22119.336 & 1951 & & & \\
\hline \multirow{3}{*}{ Tolerance } & Between Groups & 97.951 & 5 & 19.590 & \multirow{3}{*}{1.172} & \multirow{3}{*}{.321} \\
\hline & Within Groups & 32528.965 & 1946 & 16.716 & & \\
\hline & Total & 32626.916 & 1951 & & & \\
\hline \multirow{3}{*}{$\begin{array}{c}\text { Entertaining and Spending } \\
\text { Time }\end{array}$} & Between Groups & 10236.236 & 4 & 2559.059 & \multirow{3}{*}{52.689} & \multirow{3}{*}{.000} \\
\hline & Within Groups & 54883.526 & 1130 & 48.569 & & \\
\hline & Total & 65119.762 & 1134 & & & \\
\hline \multirow{3}{*}{ Maintaining a relationship } & Between Groups & 1452.107 & 4 & 363.027 & \multirow{3}{*}{34.973} & \multirow{3}{*}{.000} \\
\hline & Within Groups & 11729.514 & 1130 & 10.380 & & \\
\hline & Total & 13181.621 & 1134 & & & \\
\hline \multirow{3}{*}{ Virtual community } & Between Groups & 542.839 & 4 & 135.710 & \multirow{3}{*}{12.397} & \multirow{3}{*}{.000} \\
\hline & Within Groups & 12369.906 & 1130 & 10.947 & & \\
\hline & Total & 12912.745 & 1134 & & & \\
\hline \multirow{3}{*}{ Narcissism } & Between Groups & 6957.325 & 4 & 1739.331 & \multirow{3}{*}{13.218} & \multirow{3}{*}{.000} \\
\hline & Within Groups & 148699.401 & 1130 & 131.592 & & \\
\hline & Total & 155656.726 & 1134 & & & \\
\hline \multirow{3}{*}{$\begin{array}{l}\text { Being informed and personal } \\
\text { status }\end{array}$} & Between Groups & 471.225 & 4 & 117.806 & \multirow{3}{*}{8.434} & \multirow{3}{*}{.000} \\
\hline & Within Groups & 15783.415 & 1130 & 13.968 & & \\
\hline & Total & 16254.640 & 1134 & & & \\
\hline
\end{tabular}

According to the result of Kruskal-Wallis test, the differences between Entertaining and Spending Time and spending time were found to be significant $\left(X^{2}=171.431, \mathrm{p}<.05\right)$. In terms of this result, students preferred using social networks more and more frequent for Entertaining and Spending Time and spending time. In the dimension of maintaining a relationship $\left(\mathrm{X}^{2}=126.610, \mathrm{p}<.05\right)$, as the use of social media increased, the rate increased, as well. In terms of virtual community dimension $\left(\mathrm{X}^{2}=50.284, \mathrm{p}<.05\right)$, as the frequency of using increased, virtual community values increased, as well.

Table 4. Kruskal-Wallis Test Results Related to the Sub-Dimensions

\begin{tabular}{|c|c|c|c|c|c|}
\hline & Frequency of using social networks & $\mathrm{N}$ & Average Sum & $\mathrm{X}^{2}$ & $\mathrm{p}$ \\
\hline \multirow{5}{*}{$\begin{array}{c}\text { Entertaining and Spending Time and } \\
\text { Spending Time }\end{array}$} & $1-2$ days a month & 205 & 378.65 & \multirow{5}{*}{171.431} & \multirow{5}{*}{.000} \\
\hline & 1-2 days a week & 403 & 517.59 & & \\
\hline & 3-4 days a week & 224 & 602.31 & & \\
\hline & 5-6 days a week & 96 & 653.53 & & \\
\hline & Every day & 207 & 776.87 & & \\
\hline \multirow{5}{*}{ Maintaining a relationship } & 1-2 days a month & 205 & 385.80 & \multirow{5}{*}{126.610} & \multirow{5}{*}{.000} \\
\hline & 1-2 days a week & 403 & 537.46 & & \\
\hline & 3-4 days a week & 224 & 607.55 & & \\
\hline & 5-6 days a week & 96 & 659.26 & & \\
\hline & Every day & 207 & 722.77 & & \\
\hline \multirow{6}{*}{ Virtual community } & 1-2 days a month & 205 & 467.24 & \multirow{5}{*}{50.284} & \multirow{5}{*}{.000} \\
\hline & 1-2 days a week & 403 & 540.53 & & \\
\hline & 3-4 days a week & 224 & 577.31 & & \\
\hline & 5-6 days a week & 96 & 647.89 & & \\
\hline & Every day & 207 & 674.14 & & \\
\hline & Total & 1135 & & & \\
\hline
\end{tabular}


When the studies carried on this were reviewed, it was concluded in the thesis of Tekin Akdemir [31] upon investigation the relationships between academic delay behaviors and academic success and Facebook attitudes of the elementary education students that there were significant differences between the time for internet use and Facebook attitudes. This result supported the results of this research. The factors in this research were similar to the factors revealed in the research titled as "Motivations of Facebook, YouTube, and Similar Web Sites Users" carried out by Gülnar, Balcı and Çakır [34], and the research titled as "What is the motivation for using Facebook?" carried out by Doğruer, Meneviş and Eyyam [35]. In these researches, as well, narcissism and self-presentation motivation were determined as the factors considered as important by the users.

\subsection{Findings and Interpretation Related to the Third Sub-Problem}

Results of the one-way variance analysis test performed for answering the question of "Is there a significant difference between social media use motivations and perceived values of the secondary education students in terms of the daily internet using time?" as the third sub-problem of the research were presented in Table 5. As could be seen in ANOVA test Table, the differences between the averages of the students in virtual community dimension $\left(F_{\text {virtual }}\right.$ community $\left.10.895, p<.05\right)$, narcissism dimension $\left(\mathrm{F}_{\text {narcisisim }}=8,836, \mathrm{p}<.05\right)$, and being informed and personal status dimension ( $F$ being informed and personal status $=8,242, p<, 05$ ) were found to be significant.

Table 5. ANOVA Test Results in Terms of Internet Using Time of the Students

\begin{tabular}{|c|c|c|c|c|c|c|}
\hline & & Sum of Squares & Df & Mean Square & $\mathrm{F}$ & $\mathrm{p}$ \\
\hline \multirow{3}{*}{ Responsibility } & Between Groups & 525.505 & 4 & 131.376 & \multirow{3}{*}{6.746} & \multirow{3}{*}{.000} \\
\hline & Within Groups & 37917.470 & 1947 & 19.475 & & \\
\hline & Total & 38442.975 & 1951 & & & \\
\hline \multirow{3}{*}{ Friendship } & Between Groups & 185.624 & 4 & 46.406 & \multirow{3}{*}{2.167} & \multirow{3}{*}{.070} \\
\hline & Within Groups & 41703.461 & 1947 & 21.419 & & \\
\hline & Total & 41889.086 & 1951 & & & \\
\hline \multirow{3}{*}{ Respect } & Between Groups & 271.008 & 4 & 67.752 & \multirow{3}{*}{3.408} & \multirow{3}{*}{.009} \\
\hline & Within Groups & 38707.093 & 1947 & 19.880 & & \\
\hline & Total & 38978.102 & 1951 & & & \\
\hline \multirow{3}{*}{ Honesty } & Between Groups & 64.902 & 4 & 16.226 & \multirow{3}{*}{1.432} & \multirow{3}{*}{.221} \\
\hline & Within Groups & 22054.433 & 1947 & 11.327 & & \\
\hline & Total & 22119.336 & 1951 & & & \\
\hline \multirow{3}{*}{ Tolerance } & Between Groups & 44.562 & 4 & 11.141 & \multirow{3}{*}{.666} & \multirow{3}{*}{.616} \\
\hline & Within Groups & 32582.354 & 1947 & 16.735 & & \\
\hline & Total & 32626.916 & 1951 & & & \\
\hline \multirow{3}{*}{$\begin{array}{c}\text { Entertaining and Spending } \\
\text { Time }\end{array}$} & Between Groups & 5841.718 & 3 & 1947.239 & \multirow{3}{*}{37.153} & \multirow{3}{*}{.000} \\
\hline & Within Groups & 59278.044 & 1131 & 52.412 & & \\
\hline & Total & 65119.762 & 1134 & & & \\
\hline \multirow{3}{*}{ Maintaining a relationship } & Between Groups & 676.179 & 3 & 225.393 & \multirow{3}{*}{20.385} & \multirow{3}{*}{.000} \\
\hline & Within Groups & 12505.442 & 1131 & 11.057 & & \\
\hline & Total & 13181.621 & 1134 & & & \\
\hline \multirow{3}{*}{ Virtual community } & Between Groups & 362.689 & 3 & 120.896 & \multirow{3}{*}{10.895} & \multirow{3}{*}{.000} \\
\hline & Within Groups & 12550.057 & 1131 & 11.096 & & \\
\hline & Total & 12912.745 & 1134 & & & \\
\hline \multirow{3}{*}{ Narcissism } & Between Groups & 3564.590 & 3 & 1188.197 & \multirow{3}{*}{8.836} & \multirow{3}{*}{.000} \\
\hline & Within Groups & 152092.136 & 1131 & 134.476 & & \\
\hline & Total & 155656.726 & 1134 & & & \\
\hline \multirow{3}{*}{$\begin{array}{l}\text { Being informed and } \\
\text { personal status }\end{array}$} & Between Groups & 347.755 & 3 & 115.918 & \multirow{3}{*}{8.242} & \multirow{3}{*}{.000} \\
\hline & Within Groups & 15906.885 & 1131 & 14.064 & & \\
\hline & Total & 16254.640 & 1134 & & & \\
\hline
\end{tabular}


As a result of the Levene test, Bonferroni test was conducted with responsibility, friendship, narcissism, getting informed and personal status dimensions in order to find among which groups the significance emerged. According to the result of Bonferroni test, the sense of responsibility was higher in students who did not use the social media rather than the ones who used 1-2 days a month. In narcissism dimension, as the social media use increased, narcissist personality traits in students was noticed to increase, as well. Narcissist traits were at the highest level in students who used social media every day. Moreover, the rate increased as the social media use increased in the dimension of being informed and personal status. Results of the Kruskal-Wallis test performed in sub-dimensions of Entertaining and Spending Time and spending time, maintaining a relationship and virtual dimension were presented in Table 6. Ünişen and Demirbağ [36] [37] found that the more time allotted to computer use for reasons other than doing homework the more socially disapproved behaviors the secondary school students disposed.

According to the result of Kruskal-Wallis test, the differences between the averages of Entertaining and Spending Time and spending time were significant $\left(\mathrm{X}^{2}=171.431, \mathrm{p}<.05\right)$. Considering this result, it was possible to mention that the students preferred using social networks more and more frequently for Entertaining and Spending Time and spending time. In terms of maintaining a relationship dimension $\left(\mathrm{X}^{2}=126.610, \mathrm{p}<.05\right)$, as the social media use increased, the rate increased, as well. In terms of virtual community dimension $\left(\mathrm{X}^{2}=50.284, \mathrm{p}<.05\right)$, as the social media use increased, the rate increased, as well. Tekin Akdemir [31] (2013) mentioned that there were significant differences between internet use history and daily internet using time and the time spent daily on Facebook and Facebook attitude; and this result was coherent with the findings of this research.

Table 6. Kruskal-Wallis Test Results Related to the Sub-Dimensions

\begin{tabular}{|c|c|c|c|c|c|}
\hline & Daily internet usage time & $\mathrm{N}$ & Average Sum & $\mathrm{X}^{2}$ & $\mathrm{p}$ \\
\hline \multirow{6}{*}{ Responsibility } & Less than 1 hour & 484 & 996.25 & \multirow{6}{*}{21.024} & \multirow{6}{*}{.000} \\
\hline & 1-2 hours & 463 & 946.37 & & \\
\hline & $2-5$ hours & 145 & 897.17 & & \\
\hline & More than 5 hours & 43 & 668.40 & & \\
\hline & Nonusers & 817 & 1012.17 & & \\
\hline & Total & 1952 & & & \\
\hline \multirow{6}{*}{ Respect } & Less than 1 hour & 484 & 999.54 & \multirow{6}{*}{8.335} & \multirow{6}{*}{.080} \\
\hline & 1-2 hours & 463 & 970.44 & & \\
\hline & $2-5$ hours & 145 & 897.73 & & \\
\hline & More than 5 hours & 43 & 801.14 & & \\
\hline & Nonusers & 817 & 989.49 & & \\
\hline & Total & 1952 & & & \\
\hline \multirow{6}{*}{ Entertaining and Spending Time } & Less than 1 hour & 484 & 467.20 & \multirow{6}{*}{109.264} & \multirow{6}{*}{.000} \\
\hline & 1-2 hours & 463 & 600.48 & & \\
\hline & $2-5$ hours & 145 & 727.97 & & \\
\hline & More than 5 hours & 43 & 813.51 & & \\
\hline & Nonusers & - & & & \\
\hline & Total & 1135 & & & \\
\hline \multirow{6}{*}{ Maintaining a relationship } & Less than 1 hour & 484 & 486.65 & \multirow{6}{*}{66.794} & \multirow{6}{*}{.000} \\
\hline & $1-2$ hours & 463 & 600.52 & & \\
\hline & 2-5 hours & 145 & 680.85 & & \\
\hline & More than 5 hours & 43 & 753.01 & & \\
\hline & Nonusers & - & & & \\
\hline & Total & 1135 & & & \\
\hline
\end{tabular}




\subsection{Findings and Interpretation Related to the Fourth Sub-Problem}

The correlation analysis result performed for answering the problem of "Is there a significant relationship between social media use motivations and perceived human values of the secondary education students?" as the fourth sub-problem of the research were presented in Table 7.

As could be seen in Table 7, positive significant relationship at $46.8 \%$ level was found between the scores as result of the correlation analysis performed for determining the relationship between friendship sub-dimension and responsibility $(\mathrm{r}=0.468 ; \mathrm{p}<.05)$. According to this, as the friendship sub-dimension score increased, responsibility total score increased, as well. As result of the correlation analysis performed to determine the relationship between responsibility sub-dimension and honesty, a positive significant relationship at the level of $39.2 \%$ was found between the scores $(r=0.392 ; p<.05)$. According to this, as the score of responsibility sub-dimension increased, total score of honesty increased, as well. At the end of the correlation analysis performed for determining the relationship between responsibility sub-dimension and respect, a positive significant relationship at the level of 57\% was found between the scores $(\mathrm{r}=0.570 ; \mathrm{p}<.05)$. According to this, as the rate of respect sub-dimension increased, responsibility total score increased, as well. As result of the correlation analysis performed for determining the relationship between friendship sub-dimension and respect, a positive significant relationship at the level of $52.9 \%$ was noticed between the scores $(r=0.529 ; \mathrm{p}<.05)$.

According to this, it was possible to mention that as the score of friendship sub-dimension increased, respect total score increased, as well. At the end of the correlation analysis performed for determining the relationship between Entertaining and Spending Time and spending time sub-dimension and maintaining a relationship, a positive significant relationship at the level of $71 \%$ was found between the scores $(r=0.710 ; \mathrm{p}<.05)$.

According to this, as the rate for the Entertaining and Spending Time and spending time sub-dimension increased, maintaining a relationship total score increased, as well. As result of the correlation analysis performed for determining the relationship between Entertaining and Spending Time and spending time sub-dimension and virtual community, a positive significant relationship at the level of $52.9 \%$ was found between the scores $(r=0.529 ; \mathrm{p}<.05)$. According to this, as the rate for the Entertaining and Spending Time and spending time sub-dimension increased, virtual community total score increased, as well. 
Table 7. Correlation Analysis of the Relationship between Social Media Use Motivations and Perceived Values

\begin{tabular}{|c|c|c|c|c|c|c|c|c|c|c|c|}
\hline & & Responsibility & Friendship & Respect & Honesty & Tolerance & \begin{tabular}{|c|} 
Entertaining and \\
Spending Time \\
\end{tabular} & $\begin{array}{c}\text { Maintaining a } \\
\text { relationship }\end{array}$ & $\begin{array}{c}\text { Virtual } \\
\text { community }\end{array}$ & Narcissism & $\begin{array}{c}\text { Being informed } \\
\text { and personal status }\end{array}$ \\
\hline \multirow{3}{*}{ Responsibility } & $\mathrm{r}$ & 1 & $.468^{* *}$ & $.570^{* *}$ & $.392^{* *}$ & $.155^{* *}$ & $.181^{* *}$ & $.239^{* *}$ & $.104^{* *}$ & $.104^{* *}$ & $.199^{* *}$ \\
\hline & $\mathrm{p}$ & & .000 & .000 & .000 & .000 & .000 & .000 & .000 & .000 & .000 \\
\hline & $\mathrm{N}$ & & 1952 & 1952 & 1952 & 1952 & 1135 & 1135 & 1135 & 1135 & 1135 \\
\hline \multirow{2}{*}{ Friendship } & $\mathrm{r}$ & & 1 & $.529^{* *}$ & $.292^{* *}$ & $.158^{* *}$ & $.291^{* *}$ & $.310^{* *}$ & $.176^{* *}$ & $.182^{* *}$ & $.222^{* *}$ \\
\hline & $\mathrm{p}$ & & & .000 & .000 & .000 & .000 & .000 & .000 & .000 & .000 \\
\hline \multirow{2}{*}{ Respect } & $\mathrm{r}$ & & & 1 & $.363^{* *}$ & $.116^{* *}$ & $.224^{* *}$ & $.260^{* *}$ & $.142^{* *}$ & $.164^{* *}$ & $.265^{* *}$ \\
\hline & $\mathrm{p}$ & & & & .000 & .000 & .000 & .000 & .000 & .000 & .000 \\
\hline \multirow{2}{*}{ Honesty } & $\mathrm{r}$ & & & & 1 & $.211^{* *}$ & $.103^{* *}$ & $.161^{* *}$ & -.014 & -.046 & $.093^{* *}$ \\
\hline & $\mathrm{p}$ & & & & & .000 & .001 & .000 & .645 & .118 & .002 \\
\hline \multirow{2}{*}{ Tolerance } & $\mathrm{r}$ & & & & & 1 & $.083^{* *}$ & $.116^{* *}$ & -.049 & $-.141^{* *}$ & .029 \\
\hline & $\mathrm{p}$ & & & & & & .005 & .000 & .102 & .000 & .324 \\
\hline \multirow{2}{*}{ Entertaining and Spending Time } & $\mathrm{r}$ & & & & & & 1 & $.710^{* *}$ & $.529^{* *}$ & $.568^{* *}$ & $.563^{* *}$ \\
\hline & $\mathrm{p}$ & & & & & & & .000 & .000 & .000 & .000 \\
\hline \multirow{2}{*}{ Maintaining a relationship } & $\mathrm{r}$ & & & & & & & 1 & $.466^{* *}$ & $.433^{* *}$ & $.429^{* *}$ \\
\hline & $\mathrm{p}$ & & & & & & & & .000 & .000 & .000 \\
\hline \multirow{2}{*}{ Virtual community } & $\mathrm{r}$ & & & & & & & & 1 & $.652^{* *}$ & $.495^{* *}$ \\
\hline & $\mathrm{p}$ & & & & & & & & & .000 & .000 \\
\hline \multirow{2}{*}{ Narcissism } & $\mathrm{r}$ & & & & & & & & & 1 & $.613^{* *}$ \\
\hline & $\mathrm{p}$ & & & & & & & & & & .000 \\
\hline
\end{tabular}

**. Correlation is significant at the 0.01 level (2-tailed). 


\section{Conclusions}

It was concluded in the research that there were differences in social media use motivations and perceived values of the secondary education students in terms of their genders. It was also concluded that female students had higher level of responsibility value rather than the male students. Female students regarded friendship, respect, honesty, and maintaining a relationship sub-dimensions more than the male students. In virtual community, narcissism, being informed and personal status sub-dimensions, male students were noticed to leaning more towards virtual communities. In terms of narcissism sub-dimension, narcissism traits of male students (individuals' worshipping themselves, in a colloquial manner, individuals loving themselves) were noticed to be higher. In being informed and personal status sub-dimension, male students were determined to be more open to personal status and being informed on social media.

It was concluded that there were significant differences in social media use habits of the secondary education students and their attitudes towards perceived values in terms of their frequency of using the social networks. The conscious of responsibility was more in students who did not use social media rather than the ones who used 1-2 days a month. In the dimension of friendship, the distribution was higher in students who used social media every day rather than the ones who used 1-2 days a month, 1-2 days a week and who did not use. In narcissism dimension, as the social media use increased, narcissist personality traits in students increased, as well. Narcissist traits were the highest in students who used social media every day. In dimension of being informed and personal status, the rate increased as the use of social media increased. The students preferred using social networks more and more frequent in order to entertain and spend time. In dimension of maintaining a relationship, the rate increased as the use of social media increased. In dimension of virtual community, the values increased, as well, as the frequency of using increased. Upon this, media literacy course content at schools could be updated, and included in curriculums of all grades. This research could also be carried out with secondary education and high school grades.

In another result of the research, it was concluded that there were significant differences in attitudes of the secondary education students towards social media use habits and perceived values in terms of daily internet using periods. The conscious of responsibility was more in students who did not use social media rather than the ones who used 1-2 days a month. In friendship sub-dimension, the distribution was higher in students who used social media every day rather than the ones who did not use, who used 1-2 days a month and 1-2 days a week. According to the result of the test, as the social media use increased in narcissism dimension, the narcissist personality traits were noticed to increase, as well. Narcissist traits were the highest in students who used social media every day. Moreover, in being informed and personal status sub-dimension, the rate increased as the social media use increased. The students preferred using social networks more and more frequent in order to entertain and spend time. In maintaining a relationship sub-dimension, the rate increased, as well, as the social media use increased. The values increased as the frequency of use increased in virtual community dimension.

Finally, when the correlation between human values and social media habits of the students were analyzed, a positive significant relationship between friendship sub-dimension and responsibility was found in scores. As the score of friendship sub-dimension increased, responsibility total score increased, as well. At the end of the correlation analysis performed for determining the relationship between responsibility sub-dimension and honesty, a positive significant relationship was noticed between the scores. As the score of responsibility sub-dimension increased, honesty total score increased. As result of the correlation analysis performed for determining the relationship between responsibility sub-dimension and respect, a positive significant relationship was noticed between the scores. As the score of responsibility sub-dimension increased, respect total score increased, as well. At the end of the correlation analysis performed for determining the relationship between friendship sub-dimension and respect, a positive significant relationship was noticed between the scores. As the score of friendship sub-dimension increased, respect total score increased. As result of the correlation analysis performed for determining the relationship between Entertaining and Spending Time and spending time sub-dimension and maintaining a relationship, a positive significant relationship was noticed between the scores. As the score of Entertaining and Spending Time and spending time sub-dimension increased, maintaining a relationship total score increased. At the end of the correlation analysis performed for determining the relationship between Entertaining and Spending Time and spending time sub-dimension and virtual community, a positive significant relationship was noticed between the scores.

\section{Recommendations}

Social media addiction, which is relatively late defined for Turkey is of crucial importance as it has high a young and student population and widely used social media networks, all supporting the suitable conditions for the addiction. In Turkey, the problem of "internet and social network addiction" has been considered to increase gradually. The parents have remarkable responsibilities in order for this not to appear. Before reaching to a level of disease, families can introduce restrictions of use for their children, and lean their children towards different habits and hobbies. Therefore, the importance emphasized on values education has increased. The studies fulfilled only at schools for providing students to 
gain pre-determined values, and supporting of teachers, school managers and other employees is not adequate. Families should also support the studies on values education at schools, and be a role model for their children in consistent with this education. The students who participated into the research were noticed to take much time on Facebook. Within this framework, experts can organize various activities such as courses, seminars, etc. for efficient and productive use of social networking web sites.

In this study, social media use and using objectives of the students were investigated. Some precautions could be taken for overcoming this problem for the health of future generations carrying out such studies should with different target groups and different levels. For example, individuals could be provided to have knowledge on this through organizing seminars of experts in educational institutions at ant grades. In order for values education programs to have success, these could be provided to be maintained as a part of the curriculum at all grades of education starting from the pre-school teaching period. Visual and applied trainings apart from the courses should also be provided in order to increase the values students give on human values.

\section{REFERENCES}

[1] B. Dilmaç. An Examination of the Humane Values Education Program on a Group of Science High School Students (Doktora Tezi). Konya: Selçuk Üniv. Sosyal Bilimler Enst., 2007.

[2] F. Ök. Ortaöğretim Öğrencilerinin Sosyal Medya Kullanım Alışkanlıkları ve Motivasyonları (Master Tezi). Elazığ: Fırat Üniv., Sosyal Bilimler Enst., 2013

[3] D.R. Garrison, H. Kanuka. Blended Learning: Uncovering its Transformative Potential in Higher Education, Internet and Higher Education, 7(2), 95-105, 2004.

[4] E. Güngör. Ahlâk Psikolojisi ve Sosyal Ahlâk. İstanbul: Ötüken Yayınları, 2000.

[5] A. Çağlar. Okul Öncesi Dönemde Değerler Eğitimi. Erken Çocuklukta Gelişim ve Eğitimde Yeni Yaklaşımlar. İstanbul: Morpa Kültür Yayınları, 2005.

[6] MEB. Fatih Projesi. http://fatihprojesi.meb.gov.tr/, 2015.

[7] R. Poynter. The Handbook of Online and Social Media Research, West Sussex: John Wiley \& Sons Ltd, 2010.

[8] Y. Gülbahar, F. Kalelioğlu, O. Madran. Sosyal Ağların Eğitim Amaçlı Kullanımı, XV. Türkiye'de İnternet Konferansı, Istanbul Teknik Üniversitesi, 2010.

[9] K. Lerman. Social Information Processing in News Aggregation, IEEE Internet Computing, 11(6), 16-28, 2007.

[10] M. Binark. Yeni Medya Çalışmaları, Ankara: Dipnot Yayınlar1, 2007.

[11] L.L. Paul, S.N. Lee. Impact of Internet Literacy, Internet Addiction Symptoms, and Internet Activities on Academic
Performance, Social Science Computer Review, 30(4), 403-418, 2012.

[12] E. Engelberg, L. Sjöberg. Internet Use, Social Skills, and Adjustment, Cyberpsychology and Behavior,7(1), 2004.

[13] L.H. Shaw, L.M. Gant. In defense of the internet: the relationship between Internet communication and depression, loneliness, self-esteem, and perceived social support, Cyberpsychol Behavior, 5(2): 157-71, 2002.

[14] D. Mazalin, S. Moore. Internet Use, Identity Development and Social Anxiety Among Young Adults, Behaviour Change, 21(2), 90-102, 2004.

[15] P.M. Valkenburg, J. Peter, A.P. Schouten. Friend Networking Sites and Their Relationship to Adolescents' well-being and Social Self-esteem, Cyberpsychology and Behavior, 9(5), 2006.

[16] R. Ando, M. Takahira, A. Sakamoto. The Effects of Internet Use on Junior High School Students' Loneliness and Social Support, Global Coe Program, Tokyo: Oochanomizu University, 2008.

[17] S. Livingstone, D.R. Brake. On the Rapid Rise of Social Networking Sites: New Findings and Policy Implications, Children and Society, 24(1), 75-83, 2010.

[18] M. Öztürk, Ö.E. Akgün. University Students' Purposes in Using Social Networking Sites, and Their Opinions on Using These Sites in Education, Sakarya University Journal of Education, 2(3), 49-67, 2012.

[19] G. Göker, M. Demir, A. Doğan. Socialization and Sharing in the Network Society: An Empirical Research on Facebook, e-Journal of New World Sciences Academy, 2010.

[20] Z. Genç. Use of Web 2.0 Advancements in Education: A Case Study of Facebook in Education, Akademik Bilişim' 10. XII. Akademik Bilişim Konferansı. Muğla: Muğla Üniversitesi, 2010 .

[21] A. İşman, B. Hamutoğlu. Blended Student's Views About using Social Networks in Education Period: a case Study in Sakarya University, International Journal of New Trends in Arts, Sports and Science Education 2(3), 2013.

[22] T. Karademir, A. Alper. Standars of Social Networks Being a Learning Environment, 5th International Computer and Instructional Technologies Symposium, Elazığ: Firat University, 2011.

[23] C. Madge, J. Meek, J. Wellens, T. Hooley. Facebook, Social Integration and Informal Learning at University: 'It is More for Socializing and Talking to Friends About Work Than for Actually Doing Work. Learning, Media and Technology. 34(2), 141-155, 2009.

[24] Ö. Kalafat, Y. Göktaş. Sosyal Ağların Yükseköğretimde Kullanım1, 5th International Computer \& Instructional Technologies Symposium, Elazığ: Firat Universitesi, 2011.

[25] F. Tiryakioğlu, F. Erzurum. Bir Eğitim Aracı Olarak Ağların Kullanımı, 2nd International Conference on New Trends in Education and Their Implications. Antalya, 2011.

[26] A.R. Erdem. An Important Factor in University Culture: Values, Journal of Values Education, 1(4), 55-72, 2003.

[27] T.E. Başaran. Yönetimde İnsan İlişkileri, Ankara: Gül 
Yayınları, 1992.

[28] A. Doğanay. Değerler Eğitimi, Hayat Bilgisi ve Sosyal Bilgiler Öğretimi, Ed: C. Öztürk, Ankara: Pegem-A Yayıncilık, 2006.

[29] N. Karasar. Bilimsel Araştırma Metodu, Ankara: Hacettepe Taş Kitapçılık, 1984.

[30] A. Yıldırım, H. Şimşek. Sosyal Bilimlerde Nitel Araştırma Yöntemleri. Ankara: Seçkin Yayınları, 2005.

[31] N. Tekin Akdemir. İlköğretim Öğrencilerinin Facebook Tutumları ile Akademik Erteleme Davranışları ve Akademik Başarıları Arasındaki İlişkilerin İncelenmesi, Marmara Üniversitesi, Eğitim Bilimleri Enst., 2013.

[32] F.S. Argın. Ortaokul ve Lise Öğrencilerinin Sosyal Medyaya İlişkin Tutumlarının İncelenmesi (Master Tezi), İstanbul: Yeditepe Üniversitesi, Sosyal Bilimler Enst. 2013.

i This article is adapted from a part of the master's thesis under the management of Kara A. at Adryaman University
[33] A. Eser. İlköğretim Öğrencilerinin İnsani Değerler Düzeyleri ile Çevresel Tutumları Arasındaki İlişki, İstanbul: İstanbul Üniversitesi Eğitim Bilimleri Enst. 2012.

[34] B. Gülnar, Ş. Balcı, V. Çakır. Motivations of Facebook, Youtube and Similar Web Sites Users. Bilgi Dergisi, 2010.

[35] N. Doğruer, I. Meneviş, R. Eyyam. What is the Motivation for Using Facebook?, Procedia Social and Behavioral Sciences, 2011.

[36] A. Ünişen, B. Demirbağ. Ortaokul Öğrencilerinde Vandalizmin Aile ile İletișim ve Bazı Değişkenler Açısından İncelenmesi, "Eğitimde İnovasyon ve Profesyonelleşme", Ejer Congress 2015. Ankara: Hacettepe Üniversitesi, 2015.

[37] A. Ünișen, B. Demirbağ. Ortaokul Öğrencilerinde Vandalizmin Aile İlişkileri ve Bazı Değişkenler Açısından İncelenmesi. Education Sciences, 11(2), 49-60, 2016. 